\title{
Soil Stabilization and Revegetation at the INEEL Recommendations for Improvement
}

R. D. Blew

M. R. Jackson

A. D. Forman

March 2003

Idaho National Engineering and Environmental Laboratory Bechtel BWXT Idaho, LLC 


\title{
Soil Stabilization and Revegetation at the INEEL Recommendations for Improvement
}

\author{
R. D. Blew ${ }^{\mathrm{a}}$ \\ M. R. Jackson \\ A. D. Forman ${ }^{a}$ \\ March 2003 \\ a. Stoller Corporation \\ Idaho National Engineering and Environmental Laboratory \\ Idaho Falls, Idaho 83415
}

\author{
Prepared for the \\ U.S. Department of Energy \\ Assistant Secretary for Environmental Management \\ Under DOE Idaho Operations Office \\ Contract DE-AC07-99ID13727
}




\title{
Soil Stabilization and Revegetation at the INEEL Recommendations for improvement.
}

\author{
Roger D. Blew, PhD, S.M. Stoller Corp. \\ Michael R. Jackson, INEEL - BBWI \\ Amy D. Forman, S.M. Stoller Corp.
}

August 16, 2002

\begin{abstract}
Soil stabilization for the INEEL Stormwater Pollution Prevention Plan (SWPPP) has mostly been by revegetation, but has experienced only limited success. Table 1. lists current SWPPP projects with revegetation activities in progress that were inspected in 2001 and the number of years the revegetation project has been active. There are a total of 46 projects listed. Of those projects, revegetation action (planting or other maintenance activities) was recommended for 35 projects. Of those, 31 were planted in 2001. Of those projects planted in 2001, 23 were being planted for at least the second time. The purpose for this report is to discuss issues associated with revegetation failures and to explore possible remedies.
\end{abstract}

\section{Introduction to the Practice of Revegetation}

There are three terms associated with revegetation that need to be defined for use in this report. Revegetation simply means to plant something; anything, on a disturbed site. This may be as simple as providing ground cover or as complex as trying to recreate the lost habitat. The complexity of any given revegetation project is a function of the objective for the project, which in turn is driven by the expected future land use for that site.

The term "reclamation" is often used in relation to revegetation. Reclamation includes revegetation, but implies that something has been done to ameliorate the effects of the disturbance. Topsoil may be brought onto the site. The existing soil material may be amended to make plant growth easier (i.e. fertilizer, mulch, contaminant removal, etc). The site may be re-contoured.

Use of the term "restoration" implies that the revegetation activities return the site to its predisturbance condition. Complete ecological restoration is most often not possible. Restoration requires a complete reconstruction of the ecosystem, which is generally beyond human ability. However, it is possible, and sometimes practical to complete a partial restoration or a restoration of certain ecosystem components.

These three terms - revegetation, reclamation and restoration - can be considered as tiers in a graded approach that reflect the level of activity required to meet the objectives for the project. Every revegetation project should have clearly stated objectives. Primary objectives for a revegetation project might include controlling soil erosion or development of a self-sustaining plant community. Secondary objectives should also be considered. These might include improving aesthetics, creating or improving wildlife habitat, providing forage for livestock, or reducing land maintenance costs. These objectives should logically flow from a land-use plan. This plan might consider Desired Future Conditions (DFCs) that is, a future land or resource 
condition that achieves a set of compatible resource goals and objectives. DFCs are used as basic 'tools for land management" by other federal agencies, especially the USDA Forest Service in their land management plans. Because the effects of land cover change due to revegetation can be a stressor on ecological resources for a very long time, it is important that there be clear agreement on the long-term expectations for future land-use (e.g., ecological resource management vs. long-term confinement of hazardous and radioactive wastes).

The objectives for revegetation should also have clearly stated goals or targets for success. There should be specific performance goals for all objectives. The objectives should address goals related to both space and time. These might include a certain amount of cover by certain species, a specified increase in wildlife habitat, a specified reduction in soil erosion, etc. Each of these targets should also specify the period of time in which they should be met.

Once objectives for a project have been set, the revegetation project itself can generally be divided into five phases.

- Site stabilization

- Seedbed preparation,

- Plant propagation

- Short-term maintenance

- Intermediate maintenance/long-term stabilization.

These five phases provide an integrating framework for planning and implementing revegetation.

The site stabilization phase addresses pre-existing site conditions that would obviously make revegetation unsuccessful. These activities might include reducing the risk of severe erosion, or evidence of weeds or a risk of their invasion. These are conditions that, left uncorrected, could severely reduce the likelihood of successful revegetation.

The goal of seedbed preparation is to create "safe sites" for seeds and conditions that promote plant growth and establishment. "Safe sites" for seeds refers to soil conditions that promote seed germination. Seeds require good seed-to-soil contact to imbibe enough water to germinate. Ideal seedbeds are firm below and above the seeding depth, composed of thoroughly tilled, friable soil and are not cloddy or compacted. It is also important in this phase to ensure that soil texture and depth are sufficient to provide adequate moisture holding capacity. Sandy soils may not hold enough moisture and clayey soils may hold water too tightly for plant uptake. Loamy soils with sufficient depth to hold enough moisture to last the growing season are generally ideal. Preparing a proper seedbed is a critical component of successful revegetation.

Given the recognized importance of seedbed preparation, the plant propagation phase tends to get the greatest amount of attention. The first step in this phase is to select the plant species to be used. This is also a critical step because, by selecting the species, it is the first step in which the final make-up of the restored plant community is considered. This step also sets the stage for determining the requirements of the maintenance phases of revegetation. The plant propagation phase also addresses the methods used to plant the species selected. It first addresses the question of whether seeds or seedlings will be planted. This is an important question because it 
has implications for both the cost of the initial implementation and on the probability of and speed toward success. Planting seeds is generally less expensive, but seedlings are nearly always quicker to establish and survive. If seeds are chosen, then the method of planting must be considered. In rangeland conditions, drill seeding is generally preferred over broadcast planting, because drilling creates "safe sites" for the seeds. Broadcasting does not.

Short-term maintenance activities can have a great impact on both the likelihood of success and the length of time for completion. This phase generally occurs during the first two to three growing seasons after planting. Issues considered here are soil fertility, weed control, herbivore control (livestock, big game, rodents, etc.) irrigation, and vehicle traffic. Implementing this phase requires routine (weekly to monthly) monitoring and quick response to remedy any situations discovered.

The final phase, intermediate maintenance and long-term stabilization, includes many of the issues addressed in short-term maintenance, but may also include the need to replant all or portions of the project site. This phase is important because it covers the transition from subsidies provided by maintenance activities to a self-sustaining plant community; the ultimate goal of revegetation.

\section{Drivers for Soil Stabilization and Revegetation on the INEEL}

There are several regulatory drivers for soil stabilization and revegetation at the INEEL. The Clean Water Act through the National Pollution Discharge Elimination System (40 CFR 122) regulates stormwater discharges. The INEEL SWPPP allows for two different methods of permanent soil stabilization. Permanent revegetation provides for control of soil erosion and sediment runoff and requires little or no long-term maintenance. Gravelling can be used for permanent soil stabilization, but must be used in conjunction with weed management on the graveled area.

Compliance with some aspects of both federal (7 USC 2814) and state (IDAPA 02.06.22) noxious weed control laws can be met using revegetation. Revegetation is identified as a method for prevention and/or control of noxious weeds. Also, Executive Order 13112, Invasive Species specifies revegetation as a control measure to limit the spread of invasive species.

The Endangered Species Act (16 USC 1531 et seq.) can require habitat restoration for species listed as endangered, threatened, or candidate. This has not yet been an issue on the INEEL, however, there is serious consideration being given to petitioning sage grouse for listing as threatened or endangered within the next year. Such a listing will likely bring with it a critical habitat designation and requirements on habitat restoration including the need to revegetate disturbed areas.

The Environmental Assessment and Plan for New Silt/Clay Source Development and Use at the Idaho National Engineering and Environmental Laboratory specifies that borrow areas will be reclaimed in the fall of each year of operation.

Solid Waste Management Rules and Standards (IDAPA 58.01.06) include provisions for seeding for final site stabilization. These rules cover operations at the CFA landfills on the INEEL. 
The National Environmental Policy Act (NEPA) (42 USC Chapter 55) and the Comprehensive Environmental Response Compensation and Liability Act (42 USC Chapter 103) processes on the INEEL evaluate the potential impacts of all proposed actions. Revegetation, soil stabilization or other forms of erosion control may be mitigation measures identified by the NEPA or CERCLA process.

\section{Causes of Revegetation Failure on the INEEL}

There are a number of possible causes for revegetation failure at the INEEL. Perhaps the single most important issue limiting revegetation is the lack of both a biological resources management plan and a long-term land-use plan for the INEEL. These plans should provide the basis for defining objectives and desired outcomes for revegetation projects. Without the guidance of those plans, the revegetation prescriptions are written based on assumptions about desired future states and land-use for the project site. These assumptions then have substantial influence over revegetation planning.

Additional problems are associated with preparing the revegetation prescription and some are related to implementation of the prescription.

\section{Problems with the prescription}

There is still a lack of understanding of methods necessary to restore sagebrush steppe vegetation and little information on site-specific revegetation limitations on the INEEL itself. There has been very little research on sagebrush steppe revegetation done in the Upper Snake River Plain. Most of the relevant research has been done in Washington, Utah, Wyoming and Colorado. Climatic and soil conditions are different enough in this region to warrant additional research to support revegetation activities at the INEEL.

There is sometimes pressure to write prescriptions that are inexpensive to implement. Even though it is well known that seedlings can provide quicker establishment, the cost $(\sim \$ 3.00$ per plant) makes the initial cost of revegetation appear very expensive. However, use of seedlings should reduce the cost of the overall revegetation project if maintenance and replanting are considered. A related issue is the lack of resources to prepare detailed prescriptions for all revegetation projects.

It is also widely recognized that locally collected seeds will, in the long term, out-perform commercially available seed collected elsewhere as well as protect native genetic divesity. Presently, there is no mechanism for collecting local seed for use in INEEL projects. This is a great limitation on preparing revegetation prescriptions.

There is often little control on the site conditions, primarily topsoil characteristics. In many cases the prescription must be written before final site conditions are known. This means that there is little or no consideration given to the first two phases of revegetation: site stabilization and topsoil preparation. 
There is also no mechanism for frequent monitoring specific to revegetation success. This is a key element of the final two phases of revegetation: short-term maintenance and intermediate maintenance/long-term stabilization.

\section{Problems with implementation}

Some problems are associated with implementation of the prescription. In some cases, the prescription is not implemented at all. In 2001, there were at least four projects where actions were recommended, but not implemented. In some cases, the implementation was not done according to the prescription. These variances included planting inappropriate species, not providing topsoil, not preparing a proper seedbed, altering compost and mulch application rates, using inappropriate planting methods, etc. In some cases, there was a failure to provide adequate maintenance activities including replanting, weed control, irrigation, traffic control etc.

In some cases, lack of record keeping and communication between programs resulted in revegetation failures. In at least one case, the vegetation on a project site was killed with herbicide by mistake. A GIS database of projects made accessible to all operations groups would have easily avoided this mistake. Because the herbicide application included a soil sterilant, additional topsoil needed to be brought in before the site could be replanted. This was done at considerable additional expense.

There are a number of reasons that implementation and maintenance are not performed per the revegetation prescription. One issue is the lack of a long-term funding mechanism for project managers (PM) to maintain revegetation projects through to success. Revegetation projects generally will require five or more years to determine if they are going to be successful. Final transition to a self-sustaining plant community may take even longer. In nearly all cases, revegetation was not an integral part of the project, but added later, usually to fulfill environmental compliance guidelines. Not including revegetation as part of the overall project leads to a number of related problems. First, it means that revegetation has not been planned and, therefore, not budgeted as part of the larger project. Because revegetation is not planned, as part of the larger project, funding for the project is lost before the revegetation is completed, or in many cases before it has been implemented.

Subcontractors have planted some of the revegetation projects on the INEEL. To date, however, subcontractors have been unwilling to provide warranties on the revegetation work. The subcontractors have only been contracted to till soil and plant seed rather than contracted to successfully revegetate the project site.

Maintenance activities such as weed control must be attended to promptly. The current planning and scheduling process can be time-consuming and cumbersome. This process can take three to six weeks. In the case of weed control, activity should happen within a week of discovering the infestation. Delaying action on such issues will lead to the need for more drastic and costly action later.

Because numerous projects are not implemented as prescribed, there is a need for knowledgeable supervision of the implementation and maintenance processes. 
Three case studies are presented in Appendix A to illustrate some of the issues described above.

\section{Coordination and Cooperation}

There are presently two entities at the INEEL, project managers (PM) and revegetation specialists (RS), who must coordinate and cooperate in the revegetation processes. Each has a unique set of responsibilities related to revegetation. The PM is responsible for providing for adequate funding, providing for implementation of the revegetation project, providing maintenance to ensure success of the revegetation project, and ensuring compliance with regulations requiring revegetation. The $\mathrm{RS}$ is responsible for preparing a revegetation prescription for the project, providing periodic inspections of revegetation projects, and providing recommendations for maintenance based on the inspections.

The RS would like to be able to provide access to locally adapted plant materials. This would include the ability to collect seed on the INEEL near the project site and to develop production plots of more commonly used species. As well, the RS requires access to better site-specific information on successful techniques and methods (i.e. local research). A great deal of information could be obtained to both support a revegetation knowledge base and maintenance of projects by monitoring and documenting the long-term success of projects.

The RS needs better communication with the PM to ensure the site is left in a condition that will promote revegetation. This could be accomplished by participation earlier in the larger projectplanning phase. This would also allow earlier input into the project budget process to ensure adequate funds are available to implement a prescription with a high probability of success. These prescriptions should include consideration for the use of seedlings or other transplants, use of soil amendments and irrigation, and timely weed control.

The PM is concerned about direction early in their planning process that provides a revegetation prescription and a reliable cost estimate for installation. The PM must also access someone to do the installation and would like a guarantee of success. They need a mechanism for funding the long-term maintenance beyond closure of the project. For the most part, their priorities compete with aspects of their programs other than revegetation. For this reason, it would likely be beneficial to hand off responsibility for long-term maintenance and accountability for long-term environmental compliance related to revegetation.

\section{Solutions Employed at Other DOE Facilities}

Other DOE sites have revegetation programs that are more successful. One primary group operates Hanford's on-site revegetation program. PMs fund this group to develop revegetation prescriptions and to implement them. Maintenance activities are funded through this group's Surveillance/Maintenance program. This group uses on-site equipment operators and laborers to do the initial installation. The prescriptions implemented often include the use of seedlings. This group also holds the responsibility for ensuring success and eventually compliance with their environmental guidelines. They have funding to collect native seed on site for use at Hanford. They have also contracted with a local farmer to maintain seed production plots. Hand collections and harvest of the production plots provides their program with a substantial portion of their seed used for revegetation. They provide weekly monitoring of revegetation projects for weed invasions. This group also has responsibilities for weed control and can implement control 
measures on revegetation projects in a timely manner. Because these two functions (revegetation and weed control) reside with the same organization, it is very unlikely that revegetation projects will be inadvertently killed by herbicide use. They conduct quantitative surveys of the revegetation projects each spring. These surveys are used to gauge success and to determine what additional actions might be needed. The group's activities are reported in the Annual Site Environmental Report (for example: PNNL-12088 UC-602). Guidance for their revegetation program is documented in a Biological Resources Management Plan (DOE/RL 9632) and a Biological Resources Mitigation Strategy Plan (DOE/RL 96-88). These two documents provide the guidance and authority for developing objectives for revegetation projects.

Rocky Flats has a similar, successful revegetation program included within its overall vegetation management program. The vegetation management program includes threatened and endangered species habitat management, weed management, and prescribed burning in addition to revegetation. Each winter they prepare an Annual Vegetation Management Plan that outlines activities to be implemented in the coming year. It appears that subcontractors do at least some of the implementation.

\section{Recommendations for the INEEL Policy-Level Issues}

There are several things that need to happen to support a change in the revegetation process. A biological resource management policy needs to be developed and integrated into a long-term land-use plan. The current Comprehensive Facility and Land Use Plan deals primarily with facilities and contaminated areas, and addresses priorities for cleanup and facility management. The plan does not provide specific guidance for post-cleanup land use nor does it define desired future ecological conditions. This guidance is essential for supporting revegetation planning.

There needs to be modifications to project planning procedures to include revegetation planning early in the design phase. Typical projects on the INEEL go through four phases.

- Pre-conceptual Planning

- Conceptual Design

- Project Execution

- Acceptance/Closeout

Currently, input to this process for revegetation occurs through the Environmental Checklist review of the project. This occurs as a bridge between the Preconceptual Planning and Conceptual Design phases and provides environmental compliance considerations to be incorporated into the Project Execution Plan and the Detailed Work Plan (See Appendix B-1). When revegetation recommendations are added during the Environmental Checklist process they are usually dealt with as compliance issues rather than as design issues. This might seem to be simply a matter of semantics, but it points to an inability of the current process to properly integrate revegetation as a part of the overall "design" of a project. If revegetation is not integrated into the project and viewed as part of the project, it likely will not receive the attention necessary to make it successful. The case studies in Appendix A illustrate this point. 
Burger ${ }^{1}$ described the similarities and differences between environmental restoration and ecological restoration (Figure 1). Recognizing the similarities between these two processes provides the conceptual basis for an integration of the two. Since many of the revegetation projects at the INEEL are done through Environmental Restoration projects, further investigation into this integration may prove useful not only for revegetation, but also for meeting long-term stewardship goals.

To facilitate that integration, initial contact with a RS should come early in project planning, preferably during the Preconceptual Planning phase. The RS would participate within each project phase (see Appendix B-2) and address the following issues:

- Preconceptual planning. Establish Project Team - The RS would be recruited as a team member. Determine Project Technical Needs - The Specialist would develop a soil stabilization plan including budget, scope and schedule for the five phases of revegetation. Prepare Conceptual Design Plan - The specialist would ensure the soil stabilization plan becomes an integral part of the Conceptual Design plan and carries through to the Environmental Checklist process. This would make the Environmental Checklist process easier to complete and reduce the likelihood of unexpected conditions or requirements resulting from the review process.

- Conceptual Design. Prepare Project Execution Plan (PEP). The plan for managing the project and is the primary agreement between the PM, project team, customer, and other stakeholders. Prepare Detailed Work Plan (DWP) - The lowest level of planning for what is to be accomplished in a 3-year period. The Specialist would review the PEP to ensure that the plan provides the detailed approach (specific organization and personnel required) and budget, scope and schedule to implement the soil stabilization plan for the specific project. The RS would work closely with the DWP team personnel to conduct planning and funding for specific projects over the next three-year period.

- Project Execution - Implement PEP Requirements/Execute Work - The Specialist would oversee the work as implemented by the PEP requirements to ensure the soil stabilization plan is executed.

- Project Acceptance/Closeout - Complete Project Closeout Activities - The Specialist would participate in project specific closeout activities.

\section{Organization and Execution Issues}

There is likely a range of options from which a solution can be drawn to improve revegetation. The range reflects the amount of responsibility held by INEEL staff versus subcontractors. The two scenarios outlined below define the extremes of that range. Possible solutions for the INEEL may be found along a continuum between those two extremes.

The "In-house" solution

One solution would be to develop a group within INEEL to oversee revegetation. The PM and the RS would use funding to the PM's home organization to support some revegetation

\footnotetext{
${ }^{1}$ Burger, J. 2000. Integrating environmental restoration and ecological restoration: Long-term stewardship at the Department of Energy. Environmental Management Vol. 26, No. 5, pp. 469-478.
} 
responsibilities. The PM's responsibilities would include contacting the RS early in the project planning and requesting adequate funding to implement the revegetation prescription. The RS's responsibilities would include preparing a cost estimate, preparing the prescription, and implementing the prescription by hiring a subcontractor or directly supervising M\&O equipment operators and laborers. Funding to the RS's home organization would be used to support the remaining revegetation responsibilities (Table 2 ).

\section{Subcontractor solution}

All revegetation could be done by subcontract from the PM to a qualified restoration contractor. In this scenario, an INEEL RS would be required to designate the species to be included in the revegetation effort in order to maintain consistency with the land-use plan. The PM then hires a subcontractor who prepares the remainder of the revegetation plan, implements the plan and provides a warranty on success of the revegetation. Hiring one subcontractor to handle all revegetation projects will likely provide continuity and economies of scale. Because of the specialized knowledge involved in implementing a successful revegetation project, it is important when selecting the subcontractor to consider technical qualifications as well as cost.

Using subcontractors exclusively has the advantage of reducing the amount of revegetation expertise needed inside INEEL and puts much of the responsibility for revegetation success on the subcontractor. However, some revegetation expertise would still be required inside INEEL to review and approve revegetation proposals and to monitor the projects to determine when they have reached their targets. It also requires that the PM maintain ultimate responsibility for environmental compliance.

\section{Legacy Project Issues}

The two solutions described above are primarily designed to address new revegetation projects. There are a number of revegetation projects on the INEEL in various stages of completion. Any solution for dealing with future revegetation projects should provide a mechanism for dealing with these legacy projects. Using the Subcontractor solution, there may need to be a separate contract to deal with these projects. Costs and warranty agreements would likely have to be considered for each individual project since they are in various stages of completion. In this case the PM would still be responsible for compliance with regulatory issues. If these legacy projects were handled using the "In House" solution, this would mean providing additional support to the RS's home organization to provide the maintenance activities necessary to bring those sites into compliance. 


\section{Summary of Key Points}

Recommendations to resolve five key issues need to be considered:

- Develop a land-use plan that guides soil stabilization and revegetation design.

- Develop a process that integrates the soil stabilization/revegetation design into the overall construction or environmental restoration project.

- Address long-term funding shortfalls. This can be done by either separating funding for soil stabilization/revegetation maintenance activities from the initial installation costs or by subcontracting the revegetation projects to a company that supplies a warranty.

- Develop RS knowledge within INEEL, or hire knowledgeable subcontractor.

- Consider additional non-project-specific revegetation activities. These include, for example, developing access to locally adapted native seed sources and research to develop better methods for revegetation. 
Table 1. Active SWPPP revegetation projects.

\begin{tabular}{|c|c|}
\hline Project & Years of Revegetation Activity \\
\hline TAN IET & 1 \\
\hline ARVFS Bunker & 5 \\
\hline Fire Station No. 2 & $5(2)^{*}$ \\
\hline CFA 678/639 D\&D & 4 \\
\hline CFA Sewage Treatment Plant & 2 \\
\hline Security Training Facility & 1 \\
\hline TAN Well Sites & 4 \\
\hline Tank Farm Interim Action & 2 \\
\hline CPP Monitoring Well & 5 \\
\hline LOFT-07 & 5 \\
\hline Buried Gas Cylinder Excavation Site & 1 \\
\hline CFA Monitoring Well Sites & 5 \\
\hline CFA Tank Farm Interim Action & 4 \\
\hline TRA Sewage Leach Pond & 4 \\
\hline ARA 21-4 Seepage Pit & 2 \\
\hline ARA 13-3 Septic Tank & 2 \\
\hline ARA 07 South Seepage & 2 \\
\hline ARA-08 & 2 \\
\hline ARA-02 & 2 \\
\hline ARA-16/ARA-25 & 2 \\
\hline PBF-MON-A-001 Well Site. & 3 \\
\hline Engineered Barriers Test Facility & 2 \\
\hline Infiltration Basin & 5 \\
\hline WAG 7 RWMC Drilling and Sampling & 3 \\
\hline Pad A. & $6+$ \\
\hline Road Rehabilitation: RWMC perimeter road, culvert on Van Buren & 4 \\
\hline INTEC Service Wastewater Disposal Facility, portion outside of INTEC & 1 \\
\hline INEEL CERCLA Disposal Facility & 1 \\
\hline WERF Storm Water Basin & 1 \\
\hline Flood Control Channel: ditch near Adams bridge & 6 \\
\hline UST CF-734 & 3 \\
\hline WAG 4 site by CF- 674 pond & 3 \\
\hline TAN-733 Water Tank Replacement & 2 \\
\hline BORAX V & $6+$ \\
\hline EBR-I & $6+$ \\
\hline Acid Pit & 3 \\
\hline SDA Active Pit surrounding area & 2 \\
\hline CFA Fire and Medical Buildings & 5 \\
\hline CFA Loop 4 Water line & 3 \\
\hline TRA Soil Borrow Area & 4 \\
\hline TRA Chem Pond Cap & 4 \\
\hline TRA North Storage Area & 4 \\
\hline TRA Riprap Stockpile Area & 4 \\
\hline RWMC Meteorological Tower & 2 \\
\hline TAN Fire Water Line & 5 \\
\hline Adams Blvd. Gravel Borrow Pit & 2 \\
\hline
\end{tabular}

${ }^{*}$ A portion of this project was planted 5 years ago and the remainder was planted 2 years ago. 
Table 2. Responsibilities for each phase of revegetation in the "In House" and Subcontractor solutions.

\begin{tabular}{|c|c|c|c|c|c|c|}
\hline \multirow[b]{3}{*}{ Task } & \multicolumn{6}{|c|}{ Responsible Party } \\
\hline & \multicolumn{3}{|c|}{ In-House Solution } & \multicolumn{3}{|c|}{ Subcontractor Solution } \\
\hline & $\begin{array}{l}\text { Project } \\
\text { Manager }\end{array}$ & $\begin{array}{l}\text { Revegetation } \\
\text { Specialist }\end{array}$ & $\begin{array}{l}\text { Subcon- } \\
\text { tractor }\end{array}$ & $\begin{array}{l}\text { Project } \\
\text { Manager }\end{array}$ & $\begin{array}{l}\text { Revegetation } \\
\text { Specialist }\end{array}$ & $\begin{array}{l}\text { Subcon- } \\
\text { tractor }\end{array}$ \\
\hline Species Mix & & $\mathrm{X}$ & & & $\mathrm{X}$ & \\
\hline Prescription & & $\mathrm{X}$ & & & & $\mathrm{X}$ \\
\hline Cost estimate & & $X$ & & $\mathrm{X}$ & & \\
\hline $\begin{array}{l}\text { Funding for } \\
\text { implementation }\end{array}$ & $\mathrm{X}$ & & & $X$ & & \\
\hline Implementation & & $\mathrm{X}$ & & & & $\mathrm{X}$ \\
\hline $\begin{array}{l}\text { Funding for } \\
\text { maintenance }\end{array}$ & & $X$ & & $X$ & & \\
\hline $\begin{array}{l}\text { Maintenance (weed } \\
\text { control, irrigation, } \\
\text { replanting, fertilization, } \\
\text { etc.) }\end{array}$ & & $\mathrm{x}$ & & & & $\mathrm{x}$ \\
\hline Monitoring success & & $\mathrm{X}$ & & & & $\mathrm{X}$ \\
\hline Ensuring success & & $\mathrm{X}$ & & & & $\mathrm{X}$ \\
\hline $\begin{array}{l}\text { Compliance with } \\
\text { regulations requiring } \\
\text { revegetation }\end{array}$ & & $X$ & & $\mathrm{X}$ & & \\
\hline $\begin{array}{l}\text { Reporting annually the } \\
\text { status of projects }\end{array}$ & & $x$ & & $x$ & $X$ & \\
\hline $\begin{array}{l}\text { Developing sources of } \\
\text { local plant material (i.e. } \\
\text { seeds) }\end{array}$ & & $X$ & & & $X$ & \\
\hline $\begin{array}{l}\text { Identifying revegetation } \\
\text { research needs. }\end{array}$ & & $\mathrm{X}$ & & & $X$ & \\
\hline
\end{tabular}

Table 3. Possible responsibilities associated with legacy projects for each phase of revegetation maintenance and completion for the "In House" and Subcontractor solutions.

\begin{tabular}{|c|c|c|c|c|c|c|}
\hline \multirow[b]{3}{*}{ Task } & \multicolumn{6}{|c|}{ Responsible Party } \\
\hline & \multicolumn{3}{|c|}{ In-House Solution } & \multicolumn{3}{|c|}{ Subcontractor Solution } \\
\hline & $\begin{array}{l}\text { Project } \\
\text { Manager }\end{array}$ & $\begin{array}{l}\text { Revegetation } \\
\text { Specialist }\end{array}$ & $\begin{array}{l}\text { Subcon- } \\
\text { tractor }\end{array}$ & $\begin{array}{l}\text { Project } \\
\text { Manager }\end{array}$ & $\begin{array}{l}\text { Revegetation } \\
\text { Specialist }\end{array}$ & $\begin{array}{l}\text { Subcon- } \\
\text { tractor }\end{array}$ \\
\hline Species Mix & & $x$ & & & $x$ & \\
\hline Cost estimate & & $\mathrm{X}$ & & $\mathrm{X}$ & & \\
\hline $\begin{array}{l}\text { Funding for } \\
\text { maintenance }\end{array}$ & & $\mathrm{X}$ & & $\mathrm{x}$ & & \\
\hline $\begin{array}{l}\text { Maintenance (weed } \\
\text { control, irrigation, } \\
\text { replanting, fertilization, } \\
\text { etc.) }\end{array}$ & & $\mathrm{X}$ & & & & $\mathrm{X}$ \\
\hline Monitoring success & & $\mathrm{X}$ & & & & $\mathrm{X}$ \\
\hline Ensuring success & & $\mathrm{X}$ & & & & $\mathrm{x}$ \\
\hline $\begin{array}{l}\text { Compliance with } \\
\text { regulations requiring } \\
\text { revegetation }\end{array}$ & & $\mathrm{X}$ & & $\mathrm{x}$ & & \\
\hline $\begin{array}{l}\text { Reporting annually the } \\
\text { status of projects }\end{array}$ & & $\mathrm{X}$ & & $\mathrm{X}$ & $\mathrm{X}$ & \\
\hline
\end{tabular}




\section{Ecological Environmental \\ Restoration Restoration}

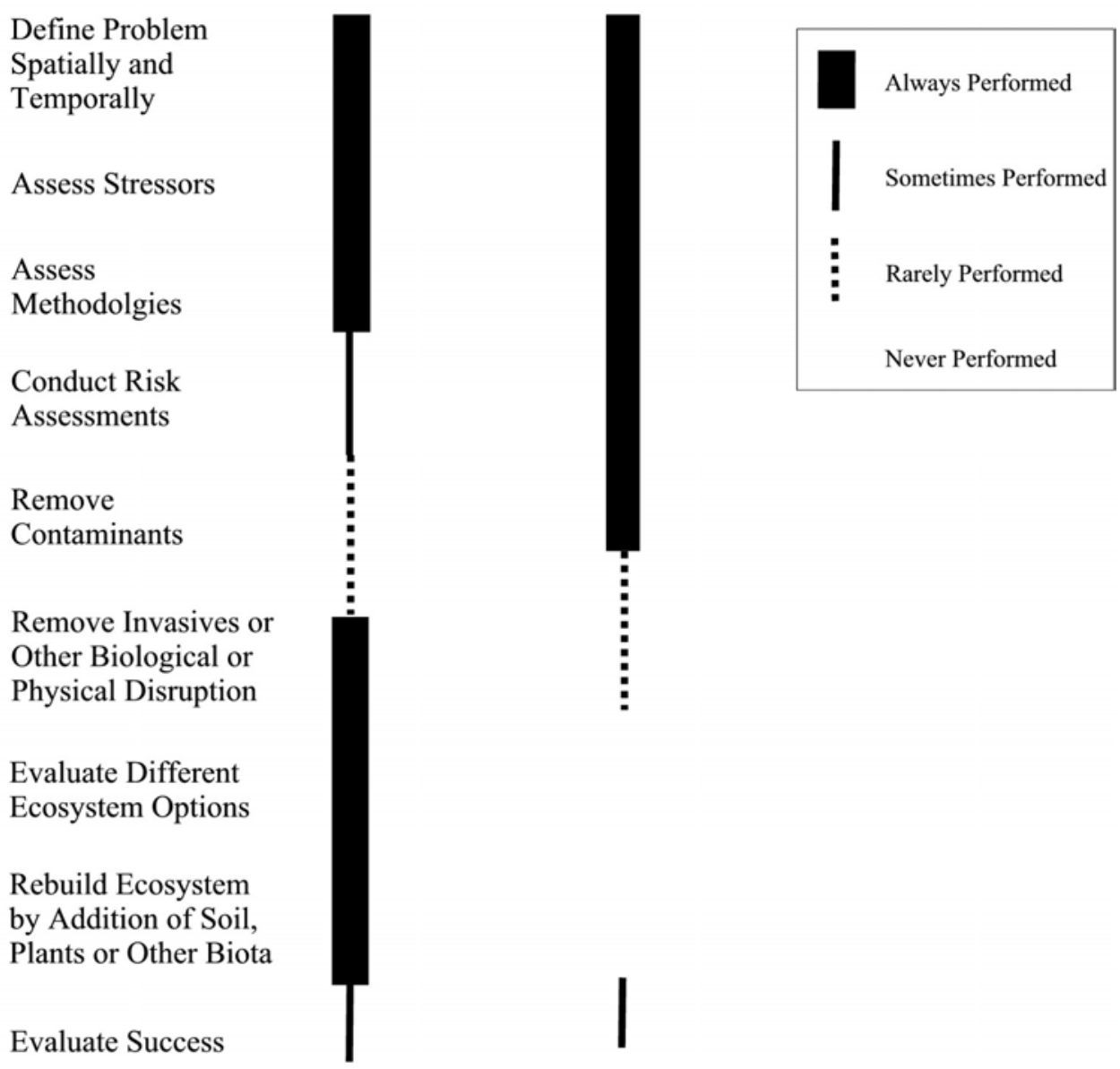

Figure 1. Overlap of ecological and environmental restoration illustrated by phases of the two processes. 


\section{Appendix A}

Case Studies 


\section{Protective Cap Biobarrier Experiment (PCBE)}

This project site was an experiment to determine the effectiveness of landfill caps consisting of native soil and native vegetation to prevent soil water from reaching buried waste. The site was excavated and simulated landfill covers constructed. The top of the simulated caps was imported silt clay loam from Spreading Area B. Because the soil was all imported, tilth was good and seedbed conditions were likely good.

Some of the plots were planted with 12 species of native plants. The first plantings were done in November 1993. Shrubs and grasses were planted as transplants. The transplants were collected within $2 \mathrm{~km}$ of the project site. Small individuals were selected for ease of transplanting. Forbs were drilled between rows of transplanted shrubs and grasses using a hand-pushed garden planter. After planting, gravel mulch was added to cover about $75 \%$ of the soil surface.

Low precipitation in 1994, the first growing season, resulted in poor growing conditions and resulted in death of many of the transplanted plants. Shrubs and grasses that had died were replaced with new transplants collected as described above. Because the dry conditions persisted, the plots were irrigated for the remainder of the 1994 growing season.

Ongoing maintenance activities included weed control. Noxious weeds (primarily Canada thistle) were sprayed with herbicide at least once each year for the first four years. Annual weeds, primarily Russian thistle, were present on the plots early in the project, but no control measures were used on them. The annual weeds disappeared when the planted vegetation became well established.

Plant cover by the end of the second growing season (1995) ranged from 20 to $25 \%$. Plant cover peaked in 1997 at about 50\%. This was primarily due to high production by grasses in response to good moisture conditions that year. By 2000, plant cover stabilized at 30 to $35 \%$. Normal native plant cover for this area is 25 to $35 \%$. If had been planted as a requirement for SWPPP, it would have approached the SWPPP target of $70 \%$ of pre-existing cover at the end of the second growing season.

There were at least five issues generally associated with revegetation at the INEEL illustrated by this project.

- Transplanted plants were used to increase the probability of establishing vegetation and to decrease the time taken to achieve success.

- The PM anticipated maintenance activities that might be required including use of supplemental irrigation, and weed control.

- The project also experienced good weather conditions in follow-up years.

- Revegetation was an integral part of the overall project.

- Adequate funding to ensure success was incorporated into the project budget. 

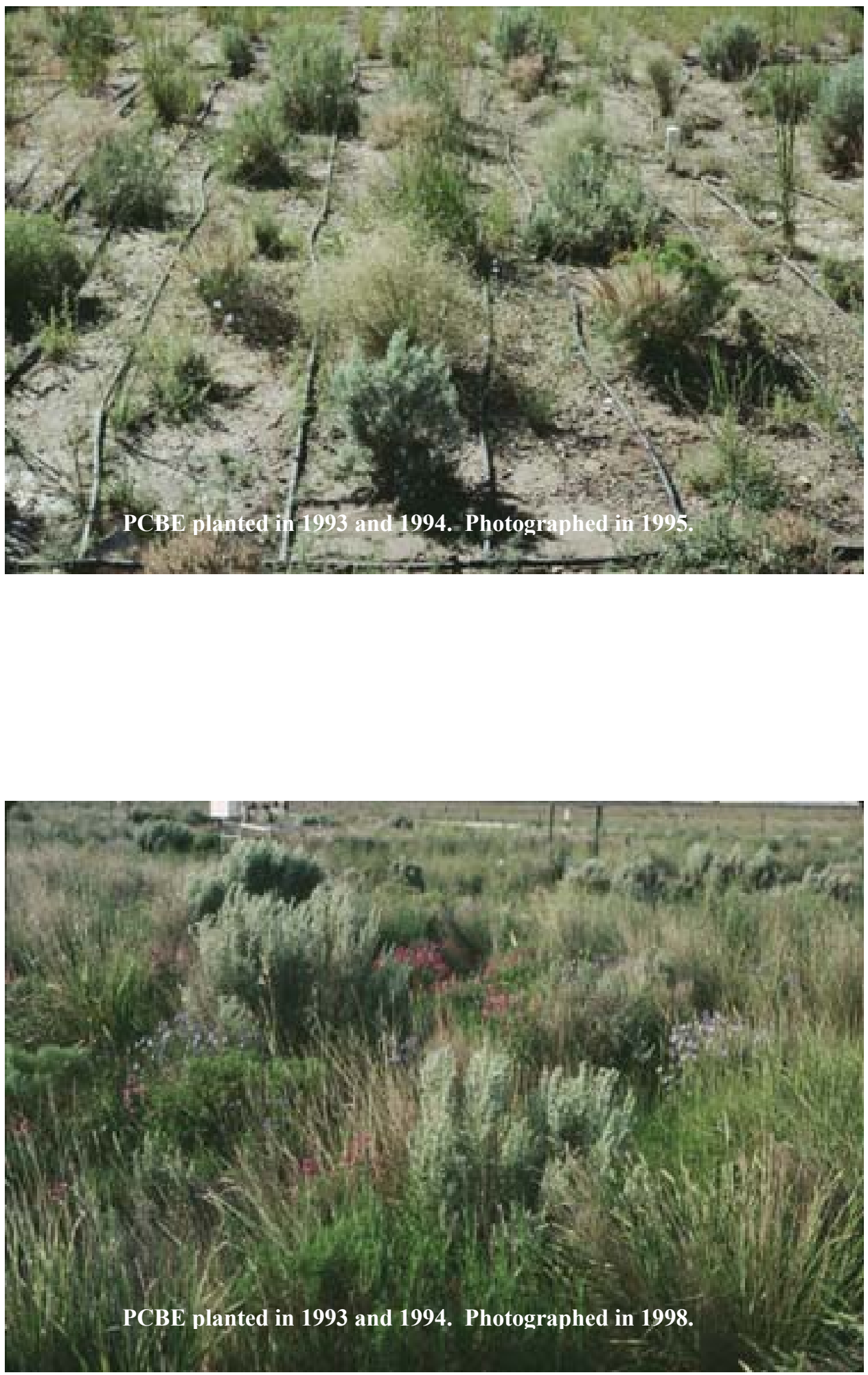


\section{CFA Landfill III}

A portion of the Landfill III cap was planted to native species in September of 1994. The seed mix included three grasses, two forbs and two shrubs. The seed was planted using a grain drill. The project site also received ammonium phosphate fertilizer at approximately 50 pounds per acre. The fertilizer was also applied using the grain drill. The site had reasonable quality topsoil conditions that contained some gravel. As in the Protective Cap/Biobarrier Experiment, some gravel can be beneficial as a mulch.

The area around the landfill is fenced off and access to the landfill cap is limited. This had the advantage of reducing or eliminating vehicle traffic on the site. The PM also conducted some management in the form of weed control. The PM also visited the site regularly.

There were reasonably good climatic conditions during the first two or three growing seasons. 1995, 1996 and 1997 were above average precipitation years with above normal rainfall in late spring. 1998 and 1999 were near normal years for precipitation.

This project experienced very good germination and establishment success. With the exception of applying the fertilizer using a drill, the prescription used in the project has been used in a number of others. The success of this project compared to many of those others is very likely due to the above average precipitation during the first two to three years following planting. During the germination and establishment periods, the plants are very sensitive to drought. Adequate moisture during those periods can greatly improve the likelihood of successful revegetation. This project has been the only one in recent years where a substantial stand of big sagebrush has been established from seed on the INEEL.

There were several issues illustrated in this case study:

- Adequate precipitation during the early years of vegetation establishment.

- Revegetation was an integral part of the overall project.

- Vehicle traffic was controlled on this site. 


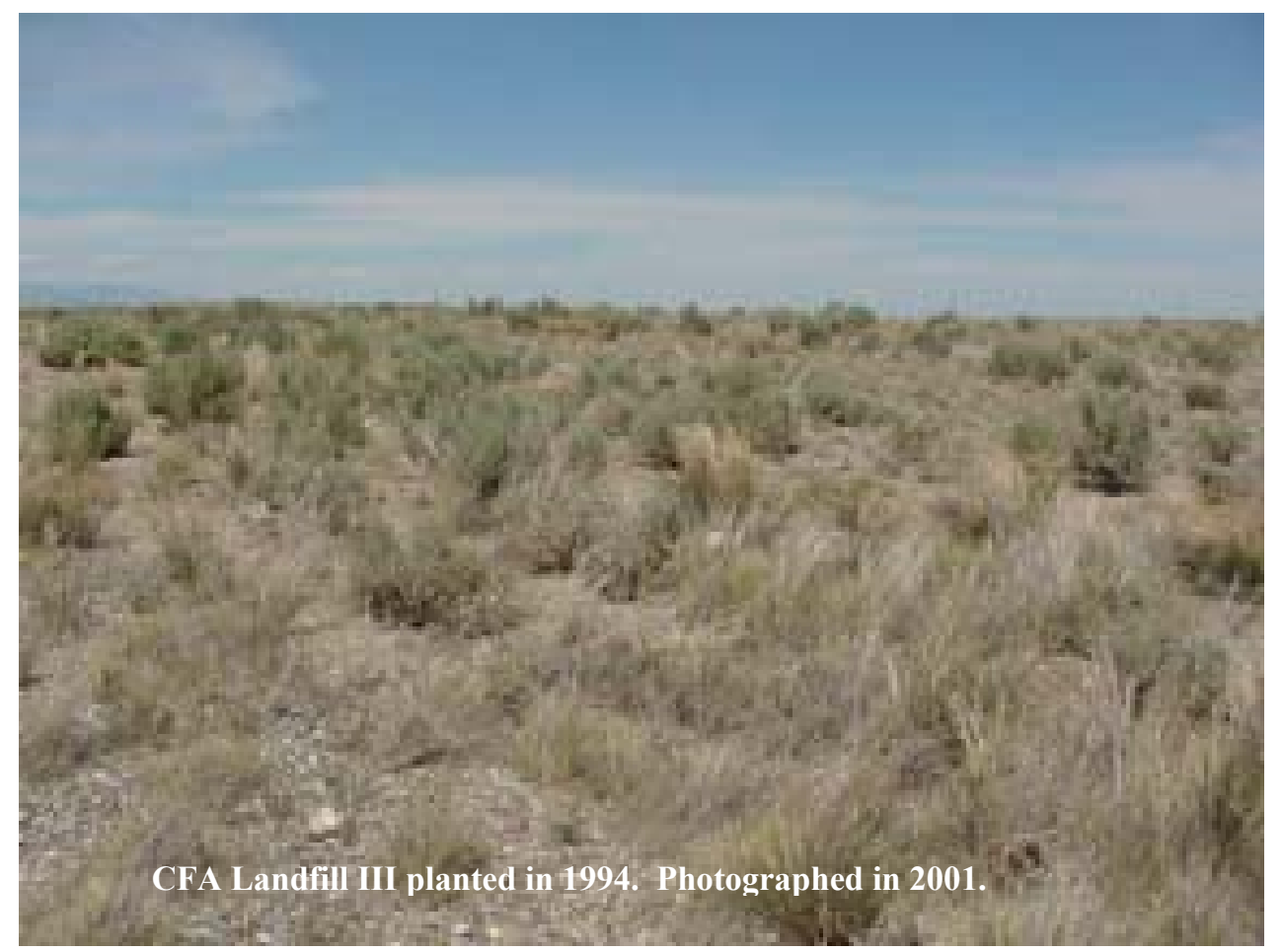




\section{Aquifer Pump and Infiltration Test Basin}

The project site was developed as a facility to test groundwater models and consisted of an area of about three acres where the topsoil was removed and then subsoil pushed up into a berm to create a basin. A number of monitoring wells were drilled inside the basin and in the surrounding area. A large production well was also drilled nearby. The basin was filled with water and the water traced as it infiltrated back to the aquifer.

The original plan called for the area to be reclaimed by pushing the subsoil in the berm back out over the basin, covering that with the stockpiled topsoil and then planted. After the experiment was completed, it was decided that the basin should remain in place to provide a laboratory for future research projects. The final plan called for the berm to remain in place, but the area would be planted to native vegetation.

Because two to three feet of soil had been removed to build the berm, the soil in the bottom of the basin was in a calcium carbonate horizon common to soils on the INEEL. This horizon, once wetted and dried creates a hard, cemented surface. This horizon is also strongly alkaline and, therefore, soil fertility can be a problem. Low available phosphorus is a common problem in these soils.

During the first tour of the site in 1997, the soil in the bottom of the basin was found to be very hard. This was likely due to a combination of factors including the calcium carbonate horizon and compaction from vehicles working in the basin. Also, a soil surfactant had been used to limit fugitive dust and may have contributed to compaction by promoting the loss of soil structure.

Relief from these conditions can be supplied by a combination of three activities. The hard soils need to be deep ripped with heavy equipment to break the compacted layer. This needs to be followed by more tillage to break down large clods to provide a better seed bed. New topsoil could be brought onto the site to bury the compacted layer. This requires that one to two feet of topsoil be brought in to promote enough root growth to maintain the plants until the roots can penetrate the compacted layer. For this project, it was recommended that the area be deep ripped, disked, and the stockpiled topsoil returned (and/or new topsoil brought in) to provide the seedbed. The topsoil removed from the site during construction had been stockpiled in a pile about $1 \mathrm{~m}$ high planted with crested wheatgrass.

The berm around the basin was also a concern for revegetation. Steep slopes are always difficult to get vegetation established. Seed tends to wash down the slope and it is difficult to get tillage and planting machinery to operate properly on slopes. Also, there was evidence of substantial vehicle traffic on the berm itself and there were numerous weeds already present.

The revegetation was implemented in October 1997. Attempts to deep rip or otherwise till the compacted soil in the bottom of the basin were unsuccessful. The field supervisor reported that the soil was so hard that it broke one of the ripper teeth so tillage activities were abandoned. The stockpiled topsoil was moved back onto the project area. Unfortunately, there was not enough topsoil to cover the entire basin floor. The available topsoil was used primarily to cover basalt 
outcrops in the basin floor. A mix of native grasses, shrubs and forbs was planted using a grain drill.

Inspections in 1999 and 2000 showed that the planted vegetation was not becoming established. Cheatgrass dominated the project areas. Some perennial grasses and forbs were present, but rare on the basin floor. It was also noted that the top of the berm had no vegetation and should be replanted and covered with erosion mats. A fence around the berm was recommended to prevent vehicle access to the berm and the basin floor. It was also recommended that a weed control program specific to annual grasses be implemented.

Additional inspections were completed in 2001. The basin floor was at that time dominated by crested wheatgrass. Crested wheatgrass is a non-native perennial grass that was not in the recommended seed mix. It was likely introduced to the basin with the topsoil. The stockpile had been planted with crested wheatgrass and there was likely seed in the soil. It may have also resprouted from roots and rhizomes.

Some native grasses and shrubs were also present in 2001. The species present were included in the 1997 seed mix. A portion of the stockpile area was still dominated by cheatgrass and annual forbs. The berm was still not recovering well. Canada thistle, a noxious weed, was found on the project area.

Several recommendations were made based on the 2001 inspection. The noxious weeds and annual weeds, primarily cheatgrass, needed to be controlled. The berm and a portion of the stockpile area needed to be replanted.

A number of issues associated with revegetation at the INEEL were illustrated by this project.

- An adequate seedbed was not established because of two related issues. The compacted soil on the basin floor was not tilled and not enough topsoil was brought onto the project site to cover the subsoil. The subsoil was a problem because it was too hard and because of the high calcium carbonate content.

- The equipment operator and field supervisor did not recognize that the drill was likely not operating properly in the hard soil. The seed was not being placed at the proper depth and the seed was not being properly covered and packed.

- Maintenance was not integrated into the project. Weed control was not implemented promptly and areas requiring replanting were not addressed. This included the berm and a portion of the stockpile area.

- Insufficient funding was available to implement all, and in some cases crucial, recommendations.

- Although the PM gated the road and put up signs noted the revegetation in progress, unauthorized vehicle traffic continued on this site. 


\section{Appendix B}

Project Flow Charts 

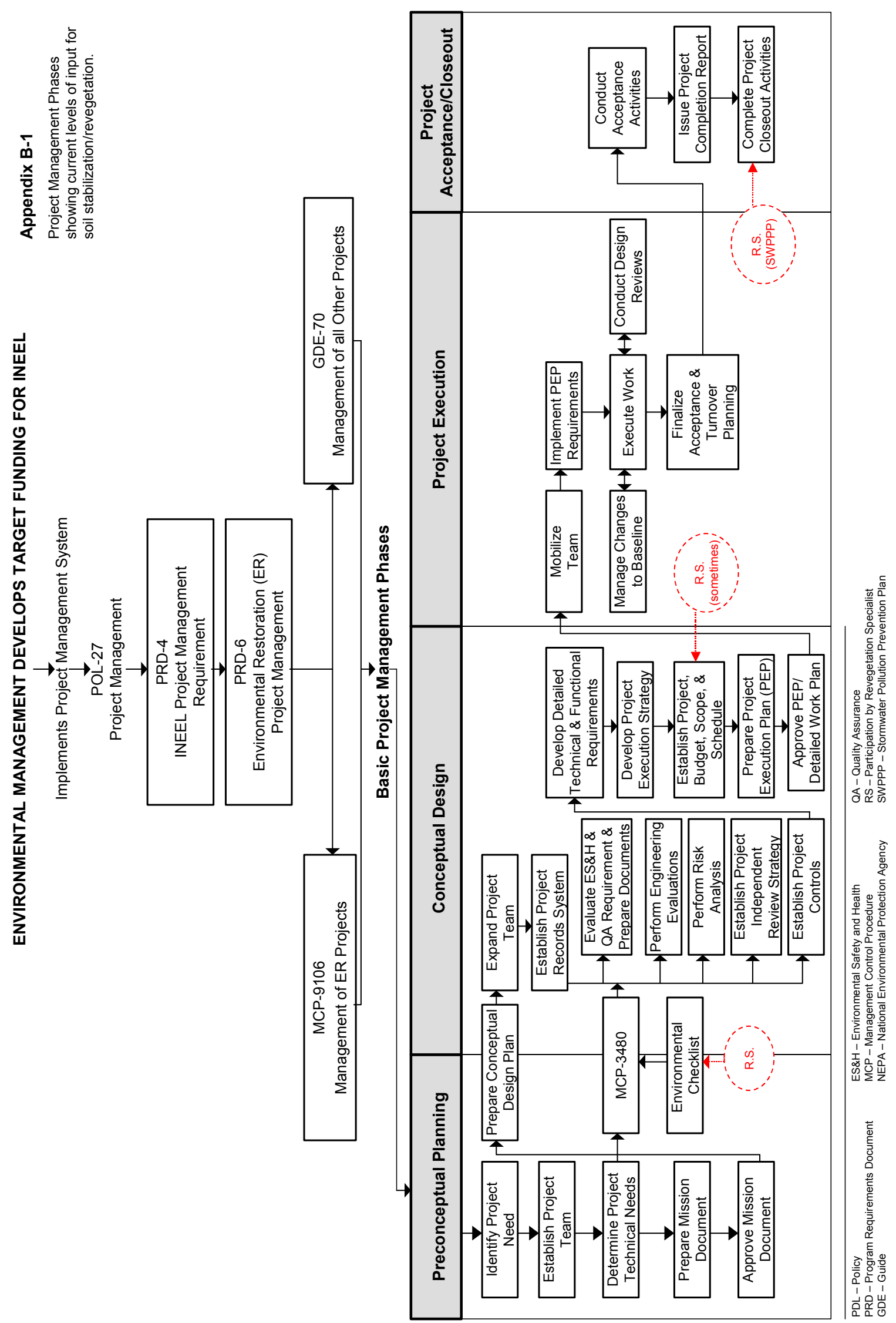

N

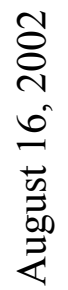



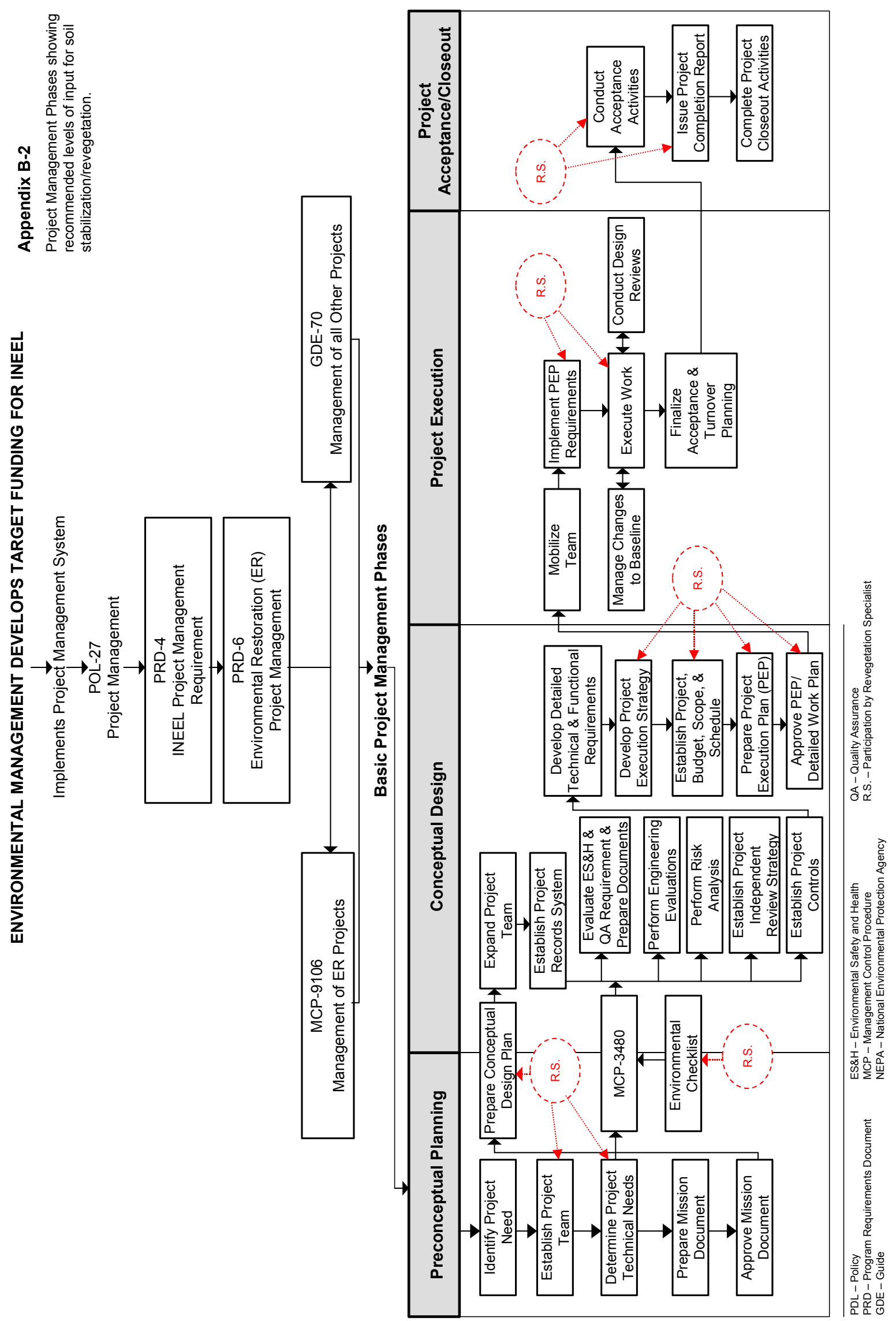

n

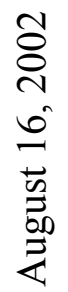

